\title{
Identity and Discourse in Securitisation Theory
}

\section{Marcos Cardoso dos Santos*}

\begin{abstract}
This article examines the complementarities among Laclau and Mouffe's discourse theory, Bourdieu's notions of habitus and field, and Huysmans's conception of discursive security strategy as a mediator of people's relation to death. The interplay among these theories explains how hegemonic security discourses emerge. The self-referential aspect of the Copenhagen School's Securitisation Theory (ST) does not contradict the existence of a relation of forces among securitising actors and audiences in given security fields, based on the ownership of social capital. This article rejects the theoretical positions adopted by Bigo, Tsoukala and Balzacq in terms of which ST is regarded as intersubjective. Utilising the discourse theory of Laclau and Mouffe, it is possible to verify how hegemonic security discourses are determined. Bourdieu's concepts of habitus and field and Huysmans's premises about security strategy also have implications for ST, mainly for the discussions about whether it has an intersubjective or self-referential aspect. As discourses of danger construct the political identities of states, the study of their influence on foreign policy is relevant to international relations. This article concludes that when the degree of otherness gets closer to the radical Other, extraordinary measures are easily tolerated by the agents involved in the securitisation process.
\end{abstract}

Keywords: Copenhagen School; discourse theory; habitus; hegemony; identity; securitisation.

\section{Introduction}

Post-structuralism has influenced many fields of knowledge since its appearance in the 1960s. This includes significant influence in the field of International Security Studies, mainly after the end of the Cold War, when realism lost its prominence due to its failure to explain this development.

The Copenhagen School disconnects itself from a security perspective that is based on the objectivity or subjectivity of threat perception. It understands security as a speech act capable of influencing the decision-making process about security issues (Buzan et al 1998: 26). This theoretical framework features the securitising actor, who performs speech acts; the referent object, which is existentially threatened; and the audience, which has to be convinced of the need to adopt emergency measures in order to guarantee the survival

\footnotetext{
* Brazilian War College, Rio de Janeiro-RJ, Brazil; marsts2011@hotmail.com. ORCID iD 0000-0002-31277032 .
} 
of the state, individual or society in question. Depending only on the illocutionary force of the speech act, and not on the audience's reaction, the Copenhagen School has characterised Securitisation Theory (ST) as self-referential (Buzan et al 1998: 24).

ST has provoked a concern with identity. Identity is capable of defining the agents' posture when faced with a securitisation initiative. The issue addressed in this article is the role of identity in securitisation processes. It adopts a post-structuralist approach, in which identity is considered as a position adopted by subjects inside security discourses (Laclau and Mouffe 2001: 115). There is no essence in identity which could lead the security analyst to believe that threats are the result of a rational choice, or historical necessity. Contingency is always present, threatening sedimented discourses whose 'naturalness' is built in such a way that they are taken for granted by decision-makers in the security field.

The debate about identity is relevant to International Relations theory, mainly the subfield of International Security Studies, because Laclau and Mouffe bring out identity as a consequence of discursive hegemonic strategies. Hegemony, in turn, has been studied in IR from a materialist perspective and not a discursive one, as the theory presented by Laclau and Mouffe (2001) attests. The first studies of hegemony in IR focused on coercive resources (i.e. military and/or economic capabilities). Eva Herschinger (2011) identifies two examples of traditional theories of hegemony in IR: the theory of hegemonic stability, and the neo-Gramscian school. According to her, the theory of hegemonic stability employs the term hegemony to explain the origins and functions of the post-1945 international economic order, conceptualising it as a structure organised around a single dominant country - the hegemon - with leadership responsibilities and privileges. Adherents to the neo-Gramscian school include Robert Cox (1983), who conceptualise hegemony as more than the dominance of a given state in the international system (Herschinger 2011: 17). Cox's theory of hegemony does not take institutions and social and power relations for granted. Although hegemony is a form of dominance, it is interpreted as the expression of a broadly based consensus that becomes manifest in the acceptance of ideas, and is supported by material resources and institutions (Cox 1981: 119). Neither of these approaches uses discourse theory or identity to explain the international politico-economic order.

The issues examined in this article are relevant to International Relations because the research about international security requires an analysis of how discourses of danger construct the political identity of states, with consequences for foreign policies involving security (Huysmans 1998: 238).

The article focuses on ST, which is discussed in terms of International Security Studies, a subfield of IR. Understanding hegemony, and consequently the formation of identities, is vital when a discursive approach is adopted to analysing security issues. To explain why some objects are regarded as threatened and others not is the goal of ST. In this respect, Buzan, Wæver and De Wilde (1998) developed a theory called 'securitisation', aimed at developing an explanation of security that could be centred not on material capabilities or subjective aspects, but on discourses, or speech acts. According to them, security is a 'quality actors inject into issues by securitising them, which means to stage them on the political arena’ (Buzan et al 1998: 204). 
This article examines the complementarity among Laclau and Mouffe's discourse theory, Bourdieu's notions of habitus and field, and Huysmans' conception of discursive security strategies as mediators of people's relation to death in order to explain how hegemonic security discourses emerge. I argue that the self-referential aspect of the Copenhagen School's Securitisation Theory does not contradict the existence of a relation of forces among securitising actors and audiences within a given security field, based on the ownership of social capital. Therefore, I take issue with Bigo, Tsoukala and Balzacq, who give ST an intersubjective character.

I will start with a review of ST from the first thoughts presented by Wæver up to his last book co-authored with Buzan and De Wilde, as well as recent articles in which ST is scrutinised in greater detail. I will examine the discourse theory of Laclau and Mouffe, analysing some aspects of identity presented in their work. Concepts like hegemony, contingency, and the 'constitutive outside' will be discussed in order to provide a theoretical framework for understanding identity as a subject position inside security discourses. Laclau and Mouffe's analysis of hegemony expresses their connection with and theoretical development of Gramsci's conception of hegemony (Laclau and Mouffe 2001: 65). Pierre Bourdieu's habitus will be analysed to explain how some dispositions are interiorised, creating a practice that manifests itself inside certain fields in which political disputes reveal the identity of individuals.

Next, taking into consideration Bourdieu's perspective, I will examine the work of Bigo and Tsoukala on securitisation to bring terms like habitus and field into a discursive analysis that will make known the limits and contributions to understanding ST. Finally, I will introduce Huysmans's notion of thick signifiers to support an argument in favour of the self-referential characteristic of securitisation. According to him, discursive security strategies constitute and mediate people's relation to death. This mediation is exercised by the state, supported by sedimented discourses that legitimise its function as the guarantor of a population's survival (Huysmans 1998: 234-5).

Against this background, the discussion needs to begin with an overview of ST, emphasising the shift from an objective to a discursive approach.

\section{The Copenhagen School's Securitisation Theory}

Securitisation was first theorised by Ole Wæver in a 1989 article entitled 'Security, the speech act: analysing the politics of a word.' He uses the philosophy of language of J L Austin (1962) to introduce a discursive approach to security that differs from the objective and subjective perspectives utilised until then. According to Austin, there are some utterances that not only describe the world, but also interfere with it, and which cannot be analysed in terms of falsity or veracity. They are simply utterances that 'do' things like betting, giving a promise, or naming a ship (Austin 1962: 5-6). Applying Austin's ideas to security, Wæver asserts that, as in speech act theory, when a state representative uses the term 'security', he or she moves the issue in question into a specific arena, claiming a special right to use the necessary means to block the threat's development (Wæver 1989: 
5-6). For Buzan et al (1998: 24-5), security does not fall in the same dimension as normal politics. To securitise an issue is to place it in a domain where emergency steps must be taken to guarantee the survival of the referent object.

Whereas Austin (1962: 14) examines the conditions that prevent speech acts from going wrong, Wæver identifies the 'facilitating conditions' for turning a speech act into a security act, namely utilising the grammar of security; exploiting the social capital of the securitising actor; and recognising or invoking the existence of conditions historically associated with a threat (Wæver, cited in Floyd 2010: 13).

The grammar of security and the social capital of the securitising actor are related to the formation of a chain of equivalences in security discourses. Social capital results from the rules that regulate the distribution of social capital within the security field. Both concepts will be discussed later.

According to Buzan et al. (1998), a securitisation process involves a securitising actor, an audience, and a referent object. The audience is defined as 'those the securitising act attempts to convince to accept exceptional procedures, because of the specific security nature of some issue' (Buzan et al. 1998: 41). Deepening the concept of audience, Wæver states that although there is a trend towards regarding a certain population or citizenry as the audience, this actually varies according to the political system and the nature of the issue (Wæver, cited in Kaunert and Léonard 2011: 59).

Going on to describe the securitisation process, Wæver says that:

In naming a certain development a security problem, the 'state' can claim a special right, one that will, in the final instance, always be defined by the state and its elites. Trying to press the kind of unwanted fundamental political change on a ruling elite is similar to playing a game in which one's opponent can change the rules at any time s/he likes. Power holders can always try to use the instrument of securitisation of an issue to gain control over it. By definition, something is a security problem when the elites declare it to be so [...] (Wæver 1995: 45, emphasis in the original).

According to Austin, speech acts can be classified as perlocutionary or illocutionary. The former refers to what happens by saying something, and the latter to the results of saying something (Austin 1962: 109). An illocutionary act constitutes a meaningful utterance coupled with a performative force. A perlocutionary act is a meaningful utterance coupled with a certain force that brings about an unconventional effect. ST makes use solely of the illocutionary act (Floyd 2010: 12). According to Austin, the locutionary act may be distinguished as 'he said that,' the illocutionary as 'he argued that', and the perlocutionary as 'he convinced me that' (Austin 1962: 102). Those points raise the issue of whether securitisation is a self-referential or intersubjective process (Balzacq 2005). In other words, is the speech act itself capable of securitising an issue, or should the audience's perception and response be added?

Floyd (2010: 54) argues that a 'securitisation is successful simply when it is brought into existence.' She rejects the idea that securitisation could be an inter-subjective process 
between a securitising actor and certain audience. She adopts a self-referential perspective on securitisation, emphasising that in questions of national security, the power to securitise is solely vested in official political authorities (Floyd 2010: 57).

By contrast, Balzacq believes the audience plays an important role in legitimising the securitising actor's decision. For him, securitisation is audience-centred, and better understood as 'a strategic (pragmatic) practice that occurs within, and as part of, a configuration of circumstances, including the context, psycho-cultural disposition of the audience, and the power that both speaker and listener bring to the interaction' (Balzacq 2005: 172).

I take the position that, using a discursive approach, with an emphasis on identity and hegemony, discussions about the self-referential and intersubjective aspects of securitisation can be theoretically mitigated. I agree with Wæver (2003: 29-30) that discourse analysis looks for the rules that govern what can be said and what cannot, and that any political construction takes place against the background of a range of sedimented practices (Laclau 1993: 35). According to Laclau, those sedimented practices are hegemonic discourses that are partially fixed. What needs to be understood is that securitisation can only take place when based on certain sedimented discourses that enable the emergence of certain security issues. As noted by Marx (1975: 103), 'men make history, but they do not make it under circumstances chosen by themselves, but under circumstances directly encountered, given and transmitted from the past.' Those circumstances are defined by the sedimented discourses in which individuals, either the audience or the securitising actor, take decisions (Laclau and Mouffe 2001: 115). The sedimented discourse is the hegemonic one, the 'we' concept that limits the possibility of security issues to be accepted by a group, albeit it a society or a political elite (Wæver 2003: 30; Laclau 1993: 35).

Aiming to widen the spectrum of security issues, the Copenhagen School proposes other elements besides the state as entities to be protected: individual, society, environment, to name just a few. In People, States and Fear (1983), Buzan presented his first attempt to discuss the notion of 'comprehensive security'. He deconstructed the notion of national security, and extended its meaning beyond the military arena. Besides the state, he identified three other units to which the concept of referent object could be applied: the individual, the region, and the international system. He also presented society, economy, and the environment as elements of the security discourse (Buzan 1991). Therefore, a referent object could be anything whose survival could be threatened, thereby justifying exceptional measures to protect it.

I will now turn to Laclau and Mouffe to outline a post-structuralist approach to the securitisation process. These authors are renowned for their theoretical support of poststructuralism.

\section{The discourse theory of Laclau and Mouffe: hegemony and the ontology of identity}

The driving force that fosters the formation of discourses, including Austin's speech acts, is the 'lack' that characterises all identity. In the strand of discourse theory used to develop 
this article, identity is contingent, lacking an essence, and understood as a subject position taken inside certain discourses (Laclau and Mouffe 2001: 115). Any subject is a 'subject of lack,' a mere void in the socio-symbolic order (Howarth 2013: 246).

How can I understand the 'lack' inherent in identity? I have to start with the notion of sign definition introduced by Saussure (1959), regarded by Howarth (2013: 24), among others, as the basic theory of post-structuralism to explain language, and how meanings are created, Saussure uses the notion of sign, formed by a signifier and a signified. The signifier is an acoustic image, and signifies the meaning given to it. The signified, nonetheless, cannot be understood in positive terms, as if it had a straight relationship with the signifier. Rather, meaning is relational, with the signified having a direct dependence upon other signs (Saussure 1959: 120). For example, understanding the term 'father' is only possible because the structure of the language also includes other signs like mother, son, daughter, and so on (Laclau and Mouffe 2001: 112-3).

Saussure compares language to a game of chess. His argument is that the pieces, by themselves, are not elements of the game. They have no significance or meaning outside the context of the game; it is only within the game that they become real, concrete elements endowed with value (Saussure 1959: 110). Therefore, language is a 'system of interdependent terms in which the value of each term results, solely, from the simultaneous presence of the others' (Saussure 1959: 114).

This relational aspect of meaning is what gives identity a 'lack.' Derrida (1982), one of the first post-structuralists, states that a signified is never complete; it is always precarious. His argument is that, following an anti-metaphysical perspective, language has no fixed centre or origin. For him 'the central signified, the original or transcendental signified, is never absolutely present outside a system of differences' (Derrida 2001: 354). Therefore, he concludes that the absence of the transcendental signified extends the domain and the play of signification infinitely (Derrida 2001: 354).

Whereas Saussure fixes the meanings inside the system, Derrida deconstructs his theory, stating that if language has no given origin or centre, the infinite play of significance and difference produced excess and lack at the same time. Excess, because the meanings are not restricted to the system itself; lack, because the system can never be closed upon itself (Derrida 1972: 62-3; Howarth 2013: 39).

Agreeing with Derrida, Laclau and Mouffe argue that meanings cannot be fixed permanently due to conflicts in the social field that defy the meanings hitherto established (Laclau and Mouffe 2001). This endless sliding of signifiers seeking meanings can only be precariously and partially resolved by the establishment of 'empty signifiers' or 'nodal points', terms that will be explained later in this article. All objects are objects of discourse, as their meanings depend on a socially constructed system of rules and significant differences (Howarth and Stavrakakis 2000: 3). To understand the formation of hegemonic discourses, it is necessary to comprehend this 'lack' of full meaning, inherent to every object of discourse, including identity. This lack is the driving force behind the formation of discourses, and the struggle for hegemony among them.

Discourse theory is not simply an idealist assumption that rules out materiality from the analysis of phenomena. Discourse incorporates material as well as ideational factors 
(Hansen 2006). For post-structuralists, the 'material' is always discursively mediated. Therefore, there is no 'extra-discursive' materiality that can be investigated by a security analyst independent of its discursive representation (Hansen 2006: 22). According to Laclau, the main concern of discourse theory is not with facts but with their conditions of possibility: 'The basic hypothesis of a discursive approach is that the very possibility of perception, thought and action depends on the structuration of a certain meaningful field which pre-exists any factual immediacy' (Laclau 1993: 541). Hence, I can only understand reality in terms of the discursive field in which I am situated.

For Laclau and Mouffe (2001), hegemony constitutes a process that fixes certain meanings, making them seem natural. The antagonism between discourses produces new meanings, countering existing ones in a counter-hegemonic process. Hence, hegemony in discourse theory is understood as a 'kind of contingent intervention required by the crisis or collapse of what would have been a "normal" historical development' (Laclau and Mouffe 2001: 7). Laclau also defines this as 'the type of political relation by which a particularity assumes the representation of an impossible universality entirely incommensurable with it. It is, as a result, a relation of transient and contingent incarnation' (Laclau 2001: 5, emphasis in the original).

Laclau and Mouffe reinterpret Gramsci's concept of hegemony from a post-structuralist perspective. Gramsci (1978: 15) holds that the choosing and criticism of a world vision are also political acts. Hegemony is about the establishment of a world conception by a specific social group, and is therefore a political act. For Gramsci, the hegemonic process is the moment when a certain group becomes aware that its own corporate interests transcend the limits of the purely economic class, and can and must become the interests of other subordinated groups too (Gramsci 1971: 181-2).

Disconnecting from a rationalist research programme, in which identities could be seen as variables to interfere with causal effects (King et al. 1995), Laclau and Mouffe refer to identities as subject positions, and Laclau specifically states that the constitution of a social identity is an act of power. One of the main thrusts in post-structuralism is to counter metaphysics and its essentialism. Based on Saussure's ideas about the relational aspect of the sign, identity has, as its condition of possibility, the establishment of a constitutive outside rather than an inner essence (Laclau 1990: 183). The constitution of any identity is based on the exclusion of that which denies it, and this exclusion is a political fact, says Laclau (1990: 33). Therefore, being an act of power, social identity has to be studied through the investigation of the power mechanisms that make it possible (Laclau 1990: 32).

According to the discourse theory of Laclau and Mouffe, the subject cannot be the agent of social change:

Whenever we use the category of 'subject' in this text, we will do so in the sense of 'subject positions' within a discursive structure. Subjects cannot, therefore, be the origin of social relations - not even in the limited sense of being endowed with powers that render an experience possible - as all 'experience' depends on precise discursive conditions of possibility (Laclau and Mouffe 2001: 115). 
Therefore, the discursive conditions of possibility are determined by the establishment of hegemonic discourses which imply the formation of identities through the logic of equivalence and difference. Those logics permit the analysis of the Self and the Other. This makes an important contribution to understanding the securitisation process, as securitisation cannot take place without antagonism, without the Other that threatens the Self's survival. At the same time, due to the lack referred to previously, the Other is also the Self's condition of possibility. Herschinger (2011: 7) argues that the Other does not necessarily constitute a threat; according to her, there are many degrees of otherness. This is relevant to an explanation of how some issues can shift, and others not, from normal politics to the realm of securitisation requiring from then on the use of extreme measures. 'Degrees of otherness' can be understood in terms of the arguments of Mouffe (2005). Explaining the difference between antagonism and agonism, Mouffe asserts that in an antagonistic political environment there are enemies, whereas in an agonistic one, there are adversaries. In contrast with an agonistic environment, in a fight against enemies, no set of rules regulate the procedure of the actors (Mouffe 2005: 20, 52). According to Mouffe, politics always consists of the creation of a 'we' versus a 'they', which requires collective identities. When these collective identities are constructed following moral categories of 'good' versus 'evil,' there is a radicalisation that foster the desire to exterminate the Other. As an example, Mouffe cites the George W. Bush administration's position on the 'war on terror,' notably his declaration that an 'axis of evil' was promoting international terrorism, and should therefore be eliminated (Mouffe 2005: 75).

Based on Mouffe's conception of antagonism and agonism, I can infer, at least at the present historical moment, that it is not possible to have antagonism among states, but only agonism. Although the international system is anarchic, I agree with Keohane (1989: 54, $55)$ that international relations operate within an issue-structure system. This type of system allows the formation of international regimes that, according to post-structuralism, can be understood as 'specific discourses,' with different degrees of sedimentation among states (Dos Santos 2016: 596). Those discourses produce a set of rules which individual states then incorporate into their domestic fields, via political decisions by elites with a bearing on their internal judicial and legislative systems. This set of rules permits the states in question to conduct their disputes in an agonistic environment as adversaries, and not as enemies.

On the other hand, when states face disputes with other political entities, like terrorist networks, the 'logic' can be different. In the 'war on terror' sponsored by the United States, it is possible to see, on both sides, the desire for complete extermination. Mouffe states that this antagonism takes place because of the 'moral register' that dominates this relation. In the 'war on terror,' the 'Other' is not seen as a 'they', but as an 'evil they. This moral register fosters the desire of extermination, and excludes any political channel of communication (Mouffe 2005: 75).

In their book entitled Hegemony and Socialist Strategy, Laclau and Mouffe introduce some significant conceptions of hegemonic strategies and the practice of articulation:

[...] we will call articulation any practice establishing a relation among elements such that their identity is modified as a result of the 
articulatory practice. The structured totality resulting from the articulatory practice, we will call discourse. The differential positions, insofar as they appear articulated within a discourse, we will call moments. By contrast, we will call element any difference that is not discursively articulated (Laclau and Mouffe 2001: 105).

The practice of articulation comprises the construction of nodal points, which partially fix meaning. They are particular elements that assume a 'universal' structuring function, and lead the chains of equivalence that make up specific hegemonic discourses (Laclau and Mouffe 2001: xi, 113).

According to Hershinger (2011: 22):

[...] a, b, c are equivalent (but not identical!) with respect to $\mathrm{z}$. Contrary to relations of difference, equivalence reduces the complexity of the discursive space, since differences are concentrated under a common reference point, the 'general equivalent.'

As laid out by Herschinger, a, b and c represent the themes that are articulated in the chain of equivalence $Z$. Each theme has its particularity as well as the universal signified that enables the relation of equivalence with other themes in the chain. $Z$ is the signifier that is tendentially empty, as it has emptied itself of its particular content, thereby representing the chain as a whole, being also part of it. The formation of the chain of equivalence produces an antagonistic frontier as its projects its lack onto something external, an antagonistic force that, in turn, forms the antagonised chain of equivalence (Herschinger 2011: 36-7).

Herschinger explains that both logics display the existence of an external element that is referential to equivalence or difference, called a nodal point in discourse theory. The study of these logics enables the researcher to understand how a given practice in a given discourse is instituted or contested. The logics of difference and equivalence are present in the discourse in the sense that one presupposes the other. Whereas the logic of difference distinguishes among the elements of a discourse, the logic of equivalence equalises those differences, thereby creating an antagonistic frontier. Despite interacting in a complex manner, neither dominates the discourse entirely, for only partial fixations of meanings are possible (Herschinger 2011: 22-3). While a hegemonic project employing the logic of equivalence seeks to divide the social field condensing meanings around two antagonistic poles, a hegemonic project employing the logic of difference attempts to weaken and dislocate a radical antagonistic polarity by striving to push such a divide out to the margins of society (Howarth and Stravakakis 2000: 11).

In order to examine securitisation, understood here as the establishment of hegemonic discourses about security issues, it is necessary to comprehend how certain themes can function as nodal points and empty signifiers, thus enabling them to lead a chain of equivalence, and form a hegemonic discourse. The political construction of identities, via the creation of hegemonic discourses, involves the production of empty signifiers that will function as nodal points (Howarth 2013: 250). Nodal points and empty signifiers are used interchangeably in the post-structuralist literature. My standpoint is that nodal 
points need to be tendentially empty. Hence, empty signifiers are potential candidates for functioning as nodal points. Howarth (2013: 251) explains that empty signifiers 'are means of representation that enable the building of alliances between different groups and identities by positing an enemy to be opposed and proposing solutions to the problems facing groups.' This is very important for understanding securitisation, and, consequently, the shift from normal politics to the use of emergency measures.

The emergence and functioning of empty signifiers require three theoretical conditions: the availability of potential empty signifiers; their credibility as a means of signification; and the presence of strategically placed agents who can construct and deploy empty signifiers (Howarth 2000: 177; Laclau 1990: 66). The last point will be discussed in the next section in which Bourdieu's notions of 'field' and 'social capital' will be analysed.

The availability and credibility of empty signifiers have to do with securitisation in the sense that they represent the kind of security issues that can be problematised, creating another security discourse, and placing the issue in question in the realm where emergency measures are required. Availability and credibility are conditioned by what Wæver (2003) calls 'layered structures.' Laclau (1990: 35) states that any political construction takes place against the background of a range of sedimented practices Therefore, the formation of hegemonic discourses depends on the existence of sedimented discourses. There are rules that govern what can be said, and the discourses that can or cannot emerge (Wæver 2003: 29-30). Howarth (2005: 323) presents these rules as social and political logics. The former are conditioned and historically specific systems of sedimented practices, and the latter refer to special kinds of practices that constitute and contest the social logics. They condition the emergence and character of the rules governing any particular social logic. The political logics are the discursive hegemonic strategies outlined by Laclau and Mouffe (2001), whereas the social logics are the range of sedimented practices (Laclau 1990). According to Wæver (2003: 32), the concept of layered structure refers to degrees of sedimentation in which 'the deeper structures are more solidly sedimented and more difficult to politicize and change, partly because they are more abstract and thereby logically implied across a wide spectrum.' Although the deeper structures are difficult to change, they contain the rules that will condition the emergence and politicisation (or securitisation) of certain issues.

Wæver's perspective is more closely related to the Self than to the Other. His investigation of the discursive articulatory strategy focuses on the elements involved in the construction of the Self (Wæver 2003: 24). It is evident that this type of analysis will result in a conception of the Other. In this epistemology, similar to the that developed by Waltz (1979: 19), Wæver wants to say a few important things based on a limited set of premises (Wæver 2003: 27). Hence, he argues that it is possible and necessary to identify specific concepts that historically have come to take on a particular importance as 'vehicles' of identity production. According to him, the investigator's task is to find small constellations of concepts that produce a nucleus of meaning, from which much of the national discourse can be generated (Wæver 2003: 24). The deeper layers are related to concepts like Nation and State (Wæver 2003: 35). Independent of the security issue to be analysed, those concepts are still relevant because, in the end, the policies in question - even those related to human, societal 
or environmental security - will be planned and executed by the state (Buzan 1991: 328). From an analysis of the elements making up the chains of equivalence of the discourses related to the concepts that make up the structured layers, it is possible to make 'negative predictions', in the sense of what cannot be 'said' within a discursive structure. Importantly, Wæver's model shows 'what is impossible, given a certain structure (and what would therefore only become possible with a deep structural change)' (Wæver 2003: 32).

Mapping the chains of equivalences and their elements, understood as 'small constellations of concepts,' allows the availability and credibility of potential 'empty signifiers' to be verified. Their availability is verified by the simple existence of the elements per se. Regarding their credibility, it is necessary to analyse the types of articulation within the discursive field that give value to the concepts in question. This value results from what Derrida (1988: 7) calls iterability, i.e., the repetition of certain codes, followed by their identification with the Other, 'the logic that ties repetition to alterity'. This relationship involving repetition and otherness achieves or promotes credibility via the partial fixation of meanings within the discursive field. The closer the degree of otherness gets to the figure of the radical Other, which represents an existential threat to a certain community, the more exceptional measures will be tolerated (Herschinger 2011: 158).

While Herschinger was not primarily concerned with layered structures, she investigated how hegemonic discourses about international terrorism and drug prohibition were construed. I see this as an example of research that uses a particular methodology to describe the formation of discourses. The same approach can be used to check, in an ST perspective, the possibility of the emergence of security discourses. Herschinger sought $\mathrm{t}$ establish the frequency of occurrences and co-occurrences of certain themes in public documents, in order to determine the formation of chains of equivalence and, consequently, verify the creation of hegemonic discourses. Drawing on the number of occurrences of certain themes, she selected potential nodal points. Her next step was to verify which selected themes were tendentially empty, a necessary condition for leading the elements to a process of identification. The emptiness can be inferred by the frequency of co-occurrences, which demonstrates the capacity of some themes to renounce their particularity in order to identify with other elements (Herschinger 2011). Wæver also investigated public texts in order to establish which codes were used when actors related to each other. This enabled him to search for structure and meaning at the exact level at which meaning is generated: in the discursive universe (Wæver 2003: 26-27, 31).

We now need to analyse Bourdieu's notions of habitus, field, and social capital, and the role of strategically placed agents capable of constructing and implementing empty signifiers.

\section{Bourdieu's concept of habitus and its implications for Securitisation Theory}

Bourdieu resorts to language and communication to show that structure and agency are not the only elements capable of explicating the nature of society. In respect of language, 
he develops the concept of power relations in order to demonstrate that, in a socially structured interaction, agents communicate in a field where social positions are already objectively structured (Bourdieu 1977). The hearer is not the one who listens to the other as a complementary element in the interaction, but the Other in a power relation that reproduces the unequal distribution of power in global society. Language is not only an instrument of communication, but also one of power. People seek, through language, to be trusted, obeyed, respected and distinguished (Bourdieu 1977: 20). Therefore, in seeking to understand the concept of habitus, it is important to bear in mind that, in contrast with the theory of Laclau and Mouffe, Bourdieu concentrates far more on the linguistic or symbolic capital distributed inside the field than on the process of discourse formation itself.

To develop the concept of habitus, Bourdieu resorts to an ancient scholastic idea that emphasises past learning. According to Ortiz:

[...] scholasticism conceived of habit as a modus operandi, i.e., as a stable disposition to operate in a certain way ... through repetition, a certain constancy was created between the subject and the object in the sense that the habit became a second dimension of the person, which effectively assured the realisation of the considered action (Ortiz 1983: 14-5, my translation).

Past learning performed by repetition has an unconscious consequence, a forgetting of history, which history itself produces through the embodiment of objective structures. Hence, in each person, there is part of yesterday's person, who inevitably predominates in everybody, since the present amounts to little compared to the long past in the course of which people were formed (Bourdieu 1995: 79).

That said, Bourdieu defines habitus as systems of durable and transposable dispositions (inclinations) that function as principles of the generation and structuring of practices without, in any way, being the product of obedience to rules, and not presupposing a conscious aiming at ends (Bourdieu 1995: 72). In his view, 'each agent, wittingly or unwittingly, $[\ldots]$ is a producer and reproducer of objective meaning. Because his actions and works are the product of a modus operandi of which he is not the producer and has no conscious mastery [...]' (Bourdieu 1995: 79). Therefore, Bourdieu makes it clear that besides the explicit norm or rational calculation, there are other principles that can generate social practices (Bourdieu 1986: 40).

One of the purposes of this article is to show that the concepts introduced by Bourdieu can also be explained in a post-structuralist perspective. To this end, Howarth usefully cites authors with a post-structuralist ontological orientation, i.e., the assumption that the essence of something is always historical, and thus marked by contingency, so that its essence is never fixed once and for all (Howarth 2013: 95). He cites a text of Bourdieu who, alongside Laclau and Mouffe, is regarded as a theorist who developed the notion of practice focusing on discourse (Howarth 2013: 106).

[...] a whole group and a whole symbolic structured environment

$[\ldots]$ exerts an anonymous, pervasive pedagogic action $[\ldots]$ the es- 
sential part of the modus operandi which defines practical mastery is transmitted in practice, in its practical state, without attaining the level of discourse. The child imitates not 'models' but other people's actions. Body hexis speaks directly to the motor function, in the form of a pattern of postures that is both individual and systematic, because linked to a whole system of techniques involving the body and tools, and charged with a host of social meanings and values [...] (Bourdieu 1995: 87, emphasis in original).

Based on the phrase 'without attaining the level of discourse', the reader could initially conclude that, for Bourdieu, there is a divide between discourse and practice. However, taking a post-structuralist approach, I argue that Bourdieu's notion of 'discourse' is not the same as that of Laclau and Mouffe. In their view, discourse is a hegemonic articulation that establishes meaning within a certain field (Laclau and Mouffe 2001). The 'pedagogic action' of the group through which the child imitates people's actions cannot take place without the existence of 'social meanings' and 'values', all products of the articulatory practice exerted between nodal points (empty signifiers) and chains of equivalence, which are able to partially fix and sediment discourses. Therefore, what Bourdieu refers to as 'discourse' in the above passage is not the system of meanings established by hegemonic discourses. This means, in turn, that it is possible to understand Bourdieu's practice and habitus as the articulatory practice theorised by Laclau and Mouffe.

For Bourdieu, discourse can only exist as long as it is socially acceptable - i. e., heard, believed, and therefore effective within a given state of social relations regulated by laws defining the social conditions of acceptability (Bourdieu 1991: 76). Discourse, for Bourdieu, is encompassed by the notion of 'institution.' He argues that this is not necessarily a particular organisation, but any relatively durable set of social relations that endows individuals with power, status and resources of various kinds. An institution defines the conditions that must be fulfilled in order for a speech act to be effective (Bourdieu 1991: 8). Therefore, the weight of different agents depends on their symbolic capital, i.e. on the recognition, institutionalised or not, that they receive from a group (Bourdieu 1991: 72).

In this way, he seeks to explain how the 'felicity conditions' for speech acts can be achieved. By virtue of being more sympathetic to Austin's theory than to Saussure's, Bourdieu takes time to develop the notion of 'felicity conditions' for a speech act to be effective. In his view, Austin was too vague, and did not understand fully that 'felicity conditions' were primarily social conditions (Bourdieu 1991: 9).

The next relevant aspect of Bourdieu's theory is the notion of field. There is a locus where the agents' positions are fixed a priori, within which those agents fight each other in order to protect and advance divergent interests. This locus is called 'field.' Sometimes, field is also called 'market', due to the competitiveness that exists within it (Bourdieu 1977: 21). According to Bourdieu (1993: 164), field is

a veritable social universe where, in accordance with its particular laws, there accumulates a particular form of capital and where rela- 
tions of force of a particular type are exerted. This universe is the place of entirely specific struggles, notably concerning the question of knowing who is part of the universe.

The relations of force inside fields play themselves out based on the struggle to accumulate different sorts of capital (Howarth 2013: 108). Some theorists, drawing on Bourdieu's assumptions, arrive at conclusions that counter the ST of the Copenhagen School. Bigo and Tsoukala, for instance, state that security issues are dealt with by professionals in a specific field, aimed at the management of unease. Therefore, the securitisation process is a political and social construction related to speech acts. But these speech acts are not decisive, for they are the result of structural competition between actors with different forms of capital and different degrees of legitimacy over contradictory definitions of security as well as interests (Bigo and Tsoukala 2008: 4-5).

Bigo and Tsoukala (2008) agree with Buzan et al. (1998) that security issues do not emerge solely from relative material capacity analysis, but are a discursive construction. However, they disagree that securitisation is about survival; instead, they argue that it is located at a level above normal politics, therefore requiring the adoption of exceptional measures, and that securitisation is self-referential.

For Bigo and Tsoukala, securitisation does not necessarily seek to guarantee the survival of a referent object. For them, it mainly has to do with sacrifice:

The knowledge of who needs to survive, be protected and from what, also supposes knowing who is sacrificed in this operation. [...] Security is also and mainly about sacrifice (Bigo \& Tsoukala 2008: 2).

Based on this standpoint, Bigo and Tsoukala develop the concept of 'ban-opticon.' They warn about illiberal measures enacted by the liberal state that reflect more than a concern about repelling threats. In their view, these measures also reflect the habitus - historical experience socialised by professional managers of unease that then enact security measures which are simply a process of social exclusion:

[...] dealing with the contemporary form of governmentality of liberal regimes that we call a ban-opticon dispositif. That dispositif is characterized by exceptionalism inside liberalism, a logic of exclusion resting upon the construction of profiles that frame who is 'abnormal' [...] All the political and professional uses of technologies of surveillance, which are oriented towards prevention and try to read the future as a 'past future' already known, thus acquire a particular importance (Bigo \& Tsoukala 2008: 2).

Bigo and Tsoukala not only emphasise the dimension of those who need to be sacrificed to guarantee security, but also that the sedimented discourses within the fields of the professional managers of unease allow the owners of social capital to enforce their opinions over the dominated. In this view, securitisation is a normal process, belonging to the professional's daily activities, and not located above politics. 
Linking this approach with the assumptions made under ST, I conclude that while social capital can explain how some agents define the emergence of empty signifiers, ST can also be regarded as self-referential.

When the securitisation process is analysed as a field, it becomes clear that the social capital which empowers the securitising actor results from a hegemonic discourse that confers the authority and duty to protect citizens against threats to their security on the state and its representatives. I argue that the main rules which govern what can be 'said' in this field are derived from a deeper layer that is intermingled with the concept of state per se. This discourse may change in the future, largely because other referent objects to be protected may be introduced. Nevertheless, thus far, the notions of Nation and State still have primacy in security issues, being the producers of codes like 'sovereignty', 'territorial integrity', 'projection of power,' 'national interest,' and so forth. As Buzan argues, regardless of the security issue in question, those concepts remain important, since, in the end, security policies are planned and implemented by the state (Buzan 1991: 328).

According to Bourdieu (1994: 55), the genesis of the state is inseparable from the unification of different social fields that goes hand in hand with the progressive constitution of the state monopoly of legitimate physical and symbolic violence. He notes that the real source of the magic of performative utterances lies in the mystery of ministry - i.e., the delegation by virtue of which an individual - king, priest, or spokesperson - is mandated to speak and act on behalf of a group. In his view, state and nation are institutions capable of equipping their representatives with the signs and the insignia the need to underline that they are not acting in their own names, and under their own authority (Bourdieu 1991: 75).

Interestingly, although the state structure empowers the representative, it 'appears' that the power is based on the qualities of the person alone (Bourdieu 1991: 73). Therefore, one of the possibilities of hegemonic discursive articulation, based on the codes issued by this deeper layer, i.e. the notion of State and Nation, is what Huysmans calls the 'thick signifier approach,' namely the 'emergence of discursive security strategies that constitute and mediate people's relation to death' (Huysmans 1998: 233). Drawing on Baudrillard's genealogy of death, Huysmans (2017: 188) concludes that death is an epistemological issue in the sense that as death is essentially unknown by humans, they need to externalise death in order to understand it. Therefore, they mediate death in two ways. The first is to constitute objects and develop countermeasures in the hope of postponing it. Thus, as a primary mediation, humans materialise death in many ways, including a foreign State or the Wrath of God. The second is to create institutions (State and Church) for mediating their relation to death (Huysmans 1998: 236-7). 'People group together because of a fear of the power of other people to kill, and because of the uncertainty about life. [...] discourses of danger construct the political identity of states, or, more generally, political communities' (Huysmans 1998: 238).

The 'subject lack' (Howarth 2013: 246) as a driving force of security discourses is manifested by the fact that citizens will always demand more security, which is fertile soil for the production of security discourses by state authorities (Huysmans 2008: 170). I understand that the self-referential aspect of ST prevails in the way in which the concept of State 
permeates all discussions on security issues. On the other hand, the concern with survival and the application of emergency measures depends on the extent to which the degree of otherness gets closer to the radical Other (Herschinger 2011: 158).

This is not an essentialist analysis of what security is for the state, but of what happens when the state speaks security. For the state, security is an ontological necessity, not because it has to be protected against external threats, but because its identity depends on them (Hansen 2006: 34). In this way, while retaining a monopoly over physical and symbolic violence (Bourdieu 1994: 55; Walker 1990: 6) the state, according to Bourdieu's notion of institution, enacts the laws of the acceptability of security discourses based on its historical development as the guarantor of the population's survival, or what Buzan calls 'the institutional expression of the state' (Buzan 1991: 65).

\section{Conclusion}

According to the Copenhagen School, security is a speech act, a quality injected into certain issues which place then in a realm above normal politics, which requires the adoption of extreme measures in order to guarantee the survival of referent objects like the state, the individual, society, or the environment (Buzan et al. 1998). Wæver adopts the concept of speech act, taken from Austin's theory of language. Speech acts not only describe the world, but are also capable of changing it, so they are performative and not constitutive. The types of speech act most relevant to ST are perlocutionary and illocutionary ones. An illocutionary act is a locution with a performative force. A perlocutionary act is a meaningful utterance possessing a certain force that produces unconventional effects. Floyd (2010: 12) asserts that ST only uses the illocutionary act. According to Austin, an illocutionary act is about the use given to words such as ask command, promise, etc. An example would be: 'He asked me (advised, commanded) to shoot her' The perlocutionary act is a meaningful locution associated with certain force that produces a non-conventional or non-contextualised effect. An example would be: 'He convinced me to shoot her' (Austin 1962: 101-2).

ST presents three agents which participate in the securitisation process: the securitising actor, who enacts the speech act; the referent object, whose survival has been threatened; and the audience, which may or may not support the securitising actor. ST has provoked many criticisms in International Security Studies. Some authors valorise the role of the audience, and define ST as intersubjective (Balzacq 2005), whereas the Copenhagen School, based on its conception of the illocutionary force of speech acts, characterises ST as self-referential (Buzan et al. 1998).

According to discourse theory, I can only understand reality in terms of the discursive field in which I am situated (Laclau and Mouffe 2001). My very possibility of 'perception, thought and action depends on the structuration of a certain meaningful field which preexists any factual immediacy' (Laclau 1993: 541). Based on the contingent aspect of identity, and on the notion of Otherness, I infer what Howarth (2013: 246) calls 'subject lack' which I consider to be the driving force of demands and hegemonic strategies in terms of 
security. Citizens will always demand more security, which implies the ongoing production of security discourses by state authorities (Huysmans 2008: 170). When the degree of otherness gets closer to the radical Other, extraordinary measures are easily tolerated (Herschinger 2011: 158). One aspect that can explain the discursive formation of a radical Other is the 'moral register' asserted by Mouffe (2005). Taking the 'war on terror' as an example, Mouffe asserts that the Other is not perceived as a 'they', but as an 'evil they'. This position foments the desire of extermination, radicalising the Other, and destroying any channel of communication.

Bourdieu (1986: 40) makes it clear that besides explicit norms or rational calculations, there are other principles that generate social practices. Thus, habitus involves systems of durable and transposable dispositions that help to generate and structure social practices (Bourdieu 1995: 72). In turn, field is a social universe featuring particular laws that regulate the accumulation of social capital, and in which relations of force are exerted (Bourdieu 1993: 164).

Wæver presents his concept of layered structures to explain which issues could be securitised (Wæver 2003: 32). The deeper layers contain the main rules that govern what can be 'said' in this field, and are intermingled with the concept of state (Wæver 2003: 32). Therefore, ST is self-referential, because the social capital that empowers the securitising actor results from deep layers of discourse that confers on the state and its representatives the authority and duty to protect the citizens against threats to their survival. Therefore, it is possible to comprehend the emergence of discursive security strategies that constitute and mediate people's relation to death, and security discourses can be seen as practices of survival (Huysmann 1998: 233).

Explaining ST in terms of a post-structuralist approach emphasises the role of identity. Due to the contingent characteristic of identity, otherness permeates all the decisionmaking process of securitisation, affecting the way in which agents perceive their worlds. The 'subject lack' is always present to the extent that, when there is no enemy or adversary, they have to be invented (Eco 2013: 8).

\section{References}

Austin, J L. 1962. How to Do Things with Words. Oxford: Oxford University Press.

Balzacq, T. 2011. 'A theory of securitisation: origins, core assumptions and variants.' In Thierry Balzacq (ed), Securitisation Theory: How security problems emerge and dissolve. New York: Routledge, pp. 1-30.

2005. 'The three faces of securitisation: political agency, audience and context.' European Journal of International Relations 11 (2): 171-201.

Baudrillard, J. 2017. Symbolic Exchange and Death. London: Sage.

Bigo, D and A Tsoukala. 2008. 'Understanding (in)security.' In Didier Bigo and Anastassia Tsoukala (eds), Terror, Insecurity and Liberty: Illiberal practices of liberal regimes after 9/11. New York: Routledge.

Bourdieu, P. 1986. 'Habitus, code et codification.' Actes de la recherche en sciences sociales 64: 40-44. 
1977. 'L'économie des échanges linguistiques.' Langue Française 34: 17-34.

1991. Language and Symbolic Power. Cambridge: Polity Press.

1995. Outline of a Theory of Practice. Cambridge: Cambridge University Press.

1994. Raisons Pratiques: Sur la théorie de l'action. Paris: Éditions du Seuil.

1993. The Field of Cultural Production: Essays on art and literature. Columbia: Columbia University Press.

Buzan, B. 1991. People, States and Fear: An agenda for international security studies in the post-Cold War era. Bodmin: MPG Books.

Buzan, B, O Wæver and J De Wilde. 1998. Security: A new framework for analysis. London: Lynne Rienner.

Cox, R W. 1983. 'Gramsci, hegemony, and international relations: An essay in method.' Millenium: Journal of International Studies 12 (2): 162-75.

1981. 'Social forces, states and world orders: beyond International Relations Theory' Millenium: Journal of International Studies 10 (2): 126-55.

Derrida, J. 1982. Margins of Philosophy. Brighton: The Harvester Press.

1997. Of Grammatology. Baltimore: John Hopkins University Press.

1972. Positions. Paris: Les Éditions de Minuit.

1988. Limited Inc. Evanston: Northwestern University Press.

2001. Writing and Difference. London: Routledge.

Dos Santos, M C. 2016. 'Catachresis, international politics and military power.' Revista da Escola de Guerra Naval [online] 22 (3): 581-606. At https://revista.egn.mar.mil.br/index.php/revistadaegn/ article/view/469/368 [Accessed on 2 February 2018].

Eco, U. 2013. Inventing the Enemy, and Other Occasional Writings. New York: Mariner Books.

Gramsci, A. 1978. Concepção Dialética da História. Translated by Carlos Nelson Coutinho. 3rd ed. Rio de Janeiro: Editora Civilização Brasileira S. A.

1971. Selections from the Prison Notebooks. Translated and edited by Quintin Hoare and Geoffrey Nowell Smith. New York: International Publishers.

Hansen, L. 2006. Security as Practice: Discourse analysis and the Bosnian war. New York: Routledge. Herschinger, E. 2011. Constructing Global Enemies: Hegemony and identity in international discourses on terrorism and drug prohibition. New York: Routledge.

Howarth, D R. 2005. 'Applying discourse theory: the method of articulation.' In D Howarth and J Torfing (eds), Discourse in European Politics: Identity, policy and governance. New York: Palgrave Macmillan, pp. 316-350. millan.

2013. Poststructuralism and After: Structure, subjectivity and power. New York: Palgrave Mac-

2000. 'The difficult emergence of a democratic imaginary: Black Consciousness and nonracial democracy in South Africa.' In D Howarth, A J Norval, J Aletta and Y Stavrakakis (eds), Discourse Theory and Political Analysis: Identities, hegemonies and social change. New York: Manchester University Press, pp. 168-192. 
Howarth, D R and Y Stavrakakis. 2000. 'Introducing discourse theory and political analysis'. In D Howarth, A J Norval, J Aletta and Y Stavrakakis (eds), Discourse Theory and Political Analysis: Identities, hegemonies and social change. New York: Manchester University Press, pp. 1-23.

Huysmans, J. 1998. 'Security! What do you mean?: From concept to thick signifier. European Journal of International Relations 4 (2): 226-255.

2008. 'The jargon of exception - on Schmitt, Agambem, and the absence of political society.' International Political Sociology 2 (2): 165-183.

Kaunert, C and S Léonard. 2011. 'Reconceptualizing the audience in securitisation theory.' In T Balzacq (ed), Securitisation Theory: How security problems emerge and dissolve. London: Routledge, pp. 57-76.

Keohane, R O. 1989. International Institutions and State Power: Essays in International Relations Theory. Boulder: Westview Press.

King, G, R O Keohane and S Verba. 1995. Designing Social Inquiry: Scientific Inference in Qualitative Research. Princeton: Princeton University Press.

Laclau, E. 1993. 'Discourse.' In R E Goodin, P Pettit and T Pogge (eds), The Blackwell Companion to Contemporary Political Philosophy. Oxford: Blackwell, pp. 541-547.

1990. New Reflections on the Revolution of our Time. New York: Verso.

Laclau, E and C Mouffe. 2001. Hegemony and Socialist Strategy: Towards a radical democratic politics. 2nd ed. New York: Verso.

Marx, K. 1975. 'The Eighteenth Brumaire of Louis Bonaparte.' In K Marx and F Engels, Collected Works, Vol XI. London: Lawrence \& Wishart, pp. 99-197.

Mouffe, C. 2005. On the Political. New York: Routledge.

Ortiz, R (ed). 1983. Pierre Bourdieu: Sociologia. São Paulo: Ática.

Saussure, F de. 1959. Course in General Linguistics. New York: Philosophical Library.

Wæver, O. 2003. 'Identity, communities and foreign policy theory'. In L Hansen and O Wæver (eds), European Integration and National Identity: The challenge of the Nordic states. New York: Routledge, pp. 20-49.

1989. 'Security, the speech act: analyzing the politics of a word.' In Research Training Seminar. Jerusalem/Tel Aviv, 25-26 June 1989. Copenhagen: Centre of Peace and Conflict Research.

. 1995. 'Securitisation and desecuritisation.' In R D Lipschutz (ed), On Security. New York: Columbia University Press, pp. 39-70.

Waltz, K N. 1979. Theory of International Politics. London: Addison-Wesley.

Walker, R B J. 1990. "Security, sovereignty, and the challenge of world politics.' Alternatives 15 (1): 3-27.

\section{About the author}

Marcos Cardoso dos Santos is professor of Scientific Research Methodology and Brazilian Strategic Environment in the graduate programme of International Security and Defence at the Brazilian War College in Rio de Janeiro. He holds a BA in Military Sciences from the Brazilian Air Force Academy, and a PhD in Political Science from Fluminense 
Federal University in Rio de Janeiro, Brazil. He has also completed the United Nations Military Observer Course at the Peace Support Training Centre in Kingston, Canada. He has experience in the fields of defence and United Nations peace operations, serving, among others, as Chief of the Public Information Office of the Military Component of the UN Stabilisation Mission in Haiti for a period of two years. His current research interest lies in using the discourse theory of Laclau and Mouffe to analyse international security and defence issues.

\section{Identidade e Discurso na Teoria da Securitisação}

Resumo: Este artigo examina as complementaridades entre a teoria do discurso de Laclau e Mouffe, as noções de habitus e campo de Bourdieu e a concepção de estratégia de segurança discursiva de Huysmans como um mediador da relação das pessoas com a morte. A interação entre essas teorias explica como surgem os discursos hegemônicos de segurança. O aspecto auto-referencial da Teoria da Securitização (ST) da Escola de Copenhague não contradiz a existência de uma relação de forças entre atores e público securitizados em determinados campos de segurança, com base na propriedade do capital social. Este artigo rejeita as posições teóricas adotadas por Bigo, Tsoukala e Balzacq em termos das quais a ST é considerada intersubjetiva. Utilizando a teoria do discurso de Laclau e Mouffe, é possível verificar como os discursos hegemônicos de segurança são estabelecidos. Os conceitos de habitus e campo de Bourdieu e as premissas de Huysmans sobre a estratégia de segurança também têm implicações para a ST, principalmente para as discussões sobre se ele tem um aspecto intersubjetivo ou auto-referencial. Como discursos de perigo constroem as identidades políticas dos Estados, o estudo de sua influência na política externa é relevante para as relações internacionais. Este artigo conclui que, quando o grau de alteridade se aproxima do radical, outras medidas extraordinárias são facilmente toleradas pelos agentes envolvidos no processo de securitização.

Palavras-chave: Escola de Copenhagen; teoria discursiva; habitus; hegemonia; identidade; secutitização.

Received on 25 October 2017, and approved for publication on 2 March 2018. 